\author{
BEATA ŁABAZ*, CEZARY KABAŁA, MICHAŁ DUDEK, JAROSŁAW WAROSZEWSKI \\ Wroclaw University of Environmental and Life Sciences, Institute of Soil Sciences and Environmental Protection \\ ul. Grunwaldzka 53, 50-357 Wroctaw, Poland
}

\title{
Morphological diversity of chernozemic soils in south-western Poland
}

\begin{abstract}
Diverse chernozemic soils featured by thick mollic horizon, rich in humus, dark-coloured, structural, and saturated with base cations are relatively common in the loess-belt of SW Poland. It is postulated, that most of these soils may have similar initial (chernozemic) history of thick humus horizon, related to climate conditions and vegetation in the Late Pleistocene and the Neolithic periods. However, these soils exist on various bedrocks and under different moisture conditions that led to the development accompanying features and variable classification of soils, both in Polish and international soil classifications. The aim of the paper is to presents the most important variants of loess-derived chernozemic soils of SW Poland, in relation to local conditions, which influenced soil transformation and present spatial diversification. 'Typical' chernozems (WRB: Calcic Chernozems), which have a mollic horizon and secondary carbonates, but are free of strong redoximorphic features, are rather uncommon in the region. Whereas, the black earths (WRB: Gleyic/Stagnic Chernozems/Phaeozems), featured by the presence of mollic horizon and strong gleyic or stagnic properties in the middle and bottom parts of the profiles, are predominant loess-derived chernozemic soils in SW Poland. Their most specific forms, developed on the clayey bedrock, are black earths with a vertic horizon (WRB: Vertic Stagnic Phaeozems). The strongly leached chernozemic soils developed over permeable subsoils, lacking carbonates and free of (strongly developed) stagnic/gleyic properties are called grey soils, often featured by the presence of subsurface diagnostic horizons cambic or luvic (WRB: Cambic/Luvic Phaeozems).
\end{abstract}

Keywords: chernozems, black earths, grey soils, mollic horizon, soil transformation

\section{INTRODUCTION}

The definition of chernozem ${ }^{1}$, presented in the sixth edition of the Polish Soil Classification 2019 (Systematyka gleb Polski 2019), emphasizes the high abundance and productivity of these soils compared with all other soils existing in the temperate climate zone. Regardless of the differences in morphological and physicochemical properties, humus horizons in all chernozemic soils are very rich in organic matter. As very fertile soils, mainly due to high content and stability of organic matter, chernozems have been valued by farmers for millennia, and, more recently, have become of interest to scientists in various fields of study (Drewnik and Żyła 2019, Kabała 2019, Łabaz et al. 2018). Chernozemic soils present in the Silesian Lowland and the Sudeten Foreland (SW Poland) have been of interest to farmers since the beginning of human settlement in the area, confirmed by common

${ }^{1}$ The common names of soil units (e.g. chernozems, black earths, grey soils) are written in lowercase unless they refer to reference soil groups of WRB, in which case they are written in capital letters.
Neolithic settlements and tombs (Kulczycka-Leciejowiczowa 1993, Kabała et al. 2019b).

Earliest mention of the genesis and age of chernozems in the Lower Silesian are provided by Orth (1872), who linked their formation to the half-swampy nature of this area at the turn of the Pleistocene and Holocene and suggested a marine origin for the dark-coloured soil material (identified by him as sapropel). In turn, Ramann (1911) was convinced of their steppe origin. Ramann noted the similarity of their morphology to Russian chernozems, defined by Dokuchaev (1883) as continental climate soils formed from carbonate-rich loess under steppe vegetation. The key argument, which justified such a comparison was the soil morphology and the silty texture of surface sediments in the Silesian Lowland, which was considered to be a typical parent material of all chernozems, not only the Russian ones. The idea of a steppe origin for chernozemic soils in the Central Europe, including the (presently) moist soils of the Lower Silesia, was very popular among German researchers (Hohenstain 1919, Stremme 1930); however, due to the dynamic development of palynological research and increasingly reliable reconstruc- 
tions of late-glacial plant communities, a forest-steppe origin of chernozems in Germany, including the Silesian Lowland area, gained acceptance (Stremme 1937). Results of Firbas (1949) paleobotanical research indicated the dominance of dense deciduous forests in Central Europe through almost the entire Holocene, narrowing the potential duration of steppe vegetation and the formation of chernozems to the Preboreal and Boreal periods.

Polish soil scientists have accepted the concept of a steppe origin of chernozems in eastern Poland, but since the 1930s they have supported the thesis of the separate, a swampy origin of moist and strongly gleyed chernozemic soils, called black earths (Miklaszewski 1930; translations of soil names after Kabała et al. 2019a). After the World War II, this concept was extended to the territories of western and northern Poland; however, Kowaliński (1952) postulated that the humus-rich soils in the Silesian Lowland couldn't have swampy origination due to their situation in landscape and thus were formed on wet meadows by the transformation of humus-gleyic soils. Their silty or loamy texture limited water permeability and prolonged the water saturation period and the presence of reduction conditions. These conditions inhibited excessive mineralization of plant debris and promoted an accumulation of humified organic matter in topsoil horizons, especially if the parent rock was rich in carbonates. In the first editions of Polish Soil Classifications after the World War II (Komisja Klasyfikacji, Nomenklatury i Klasyfikacji Gleb PTG 1956, 1959), black earths were defined as soils developed from parent materials predominately rich in carbonates, under grassy meadow vegetation supported by high ground-water table. Black earths were considered to be 'young' soils, originated in the Subboreal or even Subatlantic periods, whose present large spread had been facilitated by large-scale amelioration works carried out by farmers and settlers on former wetlands covered with murshswampy soils (Strzemski 1954). Such a description of black earths seems to be credible in relation to soils situated in depressions, where the high ground-water level clearly influenced the soil formation and properties, but it does not explain the origin of soils, which also are featured with thick humus horizons but are located on terrain elevations (Drozd et al. 2007). In addition, the high moisture of the soil profile may explain the accumulation of significant amounts of organic matter, but does not explain the large thickness of the topsoil (mineral) humus horizon (Labaz and Kabała 2014).

The most recent editions of Polish Soil Classification (Systematyka Gleb Polski 2011, 2019) underline many features common to chernozems and black earths, therefore placing them in the same order chernozemic soils - but in the separate types to stress their morphological diversity. Both soil units clearly differ in the moisture regime. Chernozems have a high water retention (related to their texture), but are featured by the lack of excessive moisture throughout the soil profile. These soils contain secondary (pedogenic) carbonates, whose larger accumulation is often the basis upon which the calcic horizon is distinguished. In turn, black earths are defined as excessively moist soils, at least seasonally (in some profiles even waterlogged), existing under imperfect drainage conditions that justifies the gleyic or stagnic properties, always present in the soil profile, albeit with varying intensity. Black earths may originate in various ways, with the participation of various geomorphological and pedogenic processes (whereby they can be considered polygenetic soils), and often with a significant contribution of humans (Łabaz and Kabała 2014).

The diverse chernozemic soils (in terms of morphological, physico-chemical and hydrological properties) chernozemic soils coexist on the hilly loess areas of the Silesian Lowland and the Sudeten Foreland (Kabała et al. 2015a). All these soils are developed of loess or loess-like sediments of varying thickness, decalcified to various degrees, and have a thick humus horizon - a mollic, often also chernic (IUSS Working Group WRB 2015). Since the soils under consideration are within the Central European loess and chernozem belt (Ukraine - southern Poland Saxony), one can presume they have a common chernozemic origin, at least in terms of the formation of thick humus horizons (Labaz et al. 2018). However, these soils are classified to various units both in Polish soil Classification (Kabała 2019, Kabała et al. 2019a) and WRB (IUSS Working Group WRB 2015).

The aim of this paper is to present the typological variability of chernozemic soils developed of loess in south-western Poland, i.e. in the Silesian Lowland and the Sudeten Foreland, and to review current opinions on their genesis and diversity in terms of morphological and physico-chemical properties, as well as their spatial distribution.

\section{STUDY AREA}

The Silesian Lowland and the neighbouring Sudeten Foreland are vast and almost flat denudation plains with an elevation between 100 and $260 \mathrm{~m}$ a.s.l., extending on both sides of the Odra river (Kondracki 2002). The current landforms were formed primarily by San and Odra glaciations, with some contribution of Warta glaciation in the northern part of the region. 
Quaternary sediments are mainly moraine tills, glacio-fluvial and alluvial sands (the latter mainly in the valley of Odra river and its tributaries). In large areas, the glacial and older sediments are covered with Late Pleistocene loess of a thickness greatly varying between 0.3 and $3.0 \mathrm{~m}$, rarely thicker (Badura et al. 2013, Jary 2010, Waroszewski et al. 2018). The area is dominated by various variants of soils featured by subsurface clay illuviation, including the Haplic/Stagnic Luvisols and Albic/Glossic Planosols (Kabała et al. 2015a). The foothills are covered by Luvisols/Luvic Stagnosols developed from slopecovers dominated by silty materials or having high admixture of aeolian silt, often in mosaics with Eutric Cambisols (Waroszewski et al. 2018; 2019). The central part of the Silesian Lowland is covered with Chernozems or Phaeozems, depending on the depth of carbonate leaching. Vertic Chernozems/Phaeozems may befound in transitions to Pellic Vertisols in the places, where loess cover is underlain with clays at the shallow depth (Dudek et al. 2019, Kabala et al. 2015b, Kabala and Musztyfaga 2016). In addition, the intra-mountain basins, even those located at relatively high altitudes, were influenced by aeolian silt accumulation during the Pleistocene period, and soil cover of these areas includes Chernozems and (more commonly) Phaeozems in addition to Luvisols (Drozd et al. 2007; Kabała et al. 2015a).

A great extent of fertile soils and a mild climate influenced the remarkably agricultural nature of the Silesian Lowland and the Sudeten Foreland. The mean annual air temperature is $8.5-9.5^{\circ} \mathrm{C}$ and the mean annual precipitation is $500 \mathrm{~mm}$ in the northern part of the Silesian Lowland and $620 \mathrm{~mm}$ in the southern periphery. The growing season is the longest in Poland and lasts about 225-235 days.

\section{MATERIALS AND METHODS}

For the comparison, soils located in an altitude range of 139-369 $\mathrm{m}$ a.s.1. were selected. They are situated in the Silesian Lowland, the Sudeten Foreland, and in the largest intra-mountain basin of the Sudeten Mountains, i.e. the Kłodzko Basin, near
Kobierzyce, Trzebnik, Łagiewniki, Mikoszów and Roszyce (Table 1). Soils were devoid of natural plant cover and were entirely used as arable land, where the cultivation of cereals (profile 1 and 2), onions (profile 3) and maize (profile 4 and 5) was carried out.

Soil samples were collected from all horizons distinguished in the soil profiles. The following properties were determined in the fine earth $(<2 \mathrm{~mm})$ particles: particle-size distribution using sieves and a hydrometer; soil $\mathrm{pH}$ in distilled water and $1 \mathrm{M} \mathrm{KCl}$, potentiometrically, at the soil:liquid ratio $1: 2.5(\mathrm{v} / \mathrm{v})$; and the calcium carbonate equivalent, by the volumetric method, using a Scheibler apparatus. Following the carbonate removal, the total organic carbon (TOC) was measured spectroscopically after dry combustion using an automatic analyser (Ströhlein CS-mat 5500). Total nitrogen (TN) content was measured using the Kjeldahl method (Büchi semi-automated analyser). The total potential acidity $(\mathrm{Hh})$, so called hydrolytic acidity, was measured by potentiometric titration after sample extraction in $1 \mathrm{M}$ ammonium chloride at $\mathrm{pH}$ 8.3. Exchangeable base cations $\left(\mathrm{Ca}^{2+}, \mathrm{K}^{+}, \mathrm{Mg}^{2+}, \mathrm{Na}^{+}\right)$ were extracted using $1 \mathrm{M}$ ammonium acetate at $\mathrm{pH} 7$ and analysed by the ICP technique. The effective cation exchange capacity and the base saturation (BS) were calculated using the sum of exchangeable base cations (BC) and the total potential acidity ( $\mathrm{Hh})$. Moreover, undisturbed soil samples were collected using stainless steel cylinders to evaluate their soil bulk density, measured using the drying-weighing method.

\section{RESULTS}

The soils under investigation occur within the extensive loess belt (profiles 1-4) or on the loess islands beyond the loess zone (profile 5), but are not always composed of loess sediments throughout the entire profile (Table 1). Profiles 1, 2 and 5 are developed from loess sediments with a minimum thickness of $150 \mathrm{~cm}$ and have a silt loam texture throughout the entire profile (Table 3 ). Profile 3 represents a typical case of soils developed from loess (silt loam texture class) in topsoil, underlain by coarser glacial sediments (sandy loam class) in the subsoil (Table 3). In turn,

TABLE 1. Situation of soil profiles in a slope catena

\begin{tabular}{lllll}
\hline Soil profile & $\begin{array}{l}\text { Altitude } \\
(\mathrm{m} \text { a.s.l.) }\end{array}$ & $\begin{array}{l}\text { Slope } \\
(\%)\end{array}$ & Land use & Parent material \\
\hline 1 (Lagiewniki) & 190 & 2 & arable field (wheat) & loess \\
\hline 2 (Trzebnik) & 170 & 1 & arable field (wheat) & loess \\
\hline 3 (Kobierzyce) & 139 & 0 & arable field (onion) & loess on till \\
\hline 4 (Mikoszów) & 169 & 8 & arable field (corn) & deluvial loam on Neogene clay \\
\hline 5 (Roszyce ) & 369 & 1 & arable field (corn) & loess \\
\hline
\end{tabular}




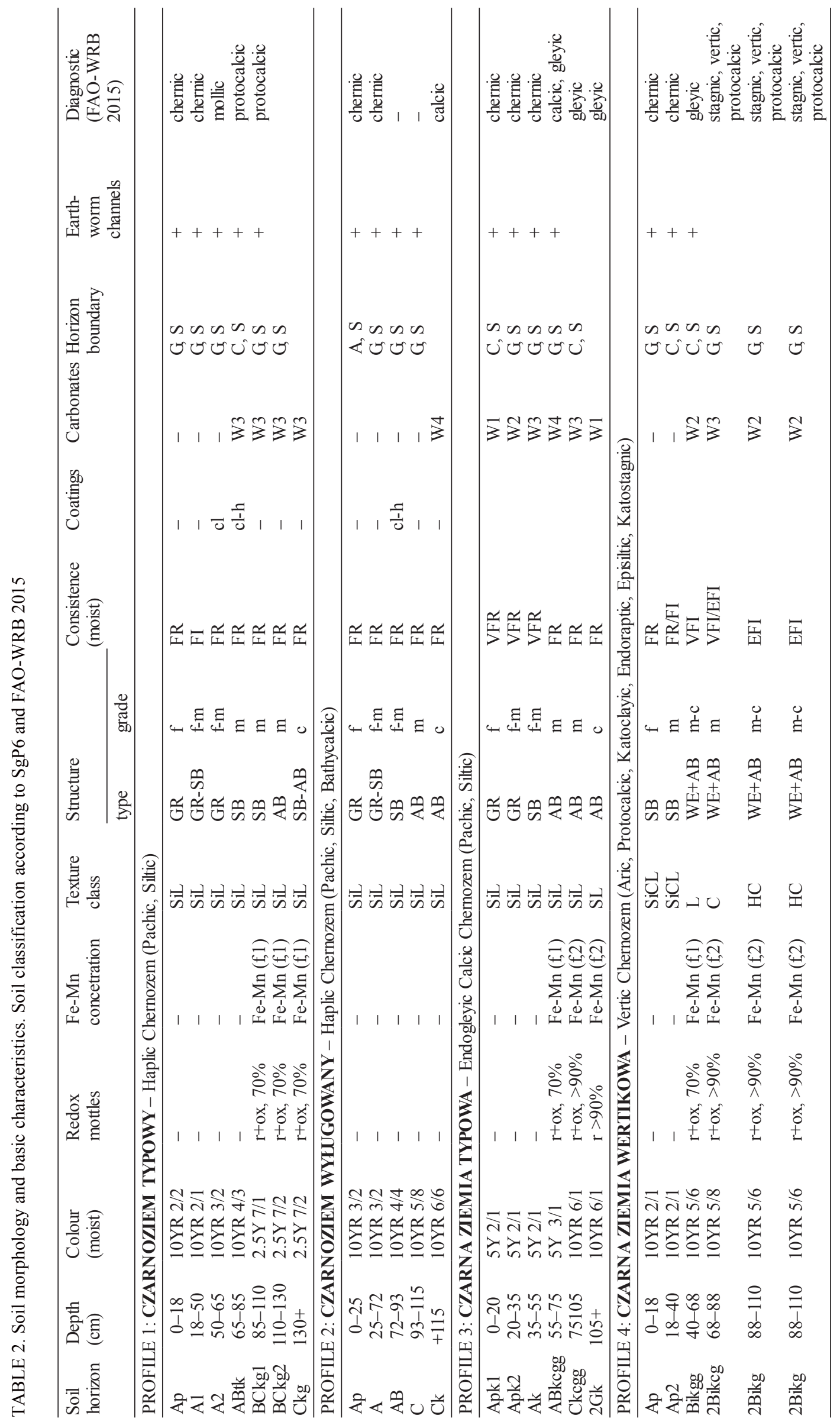




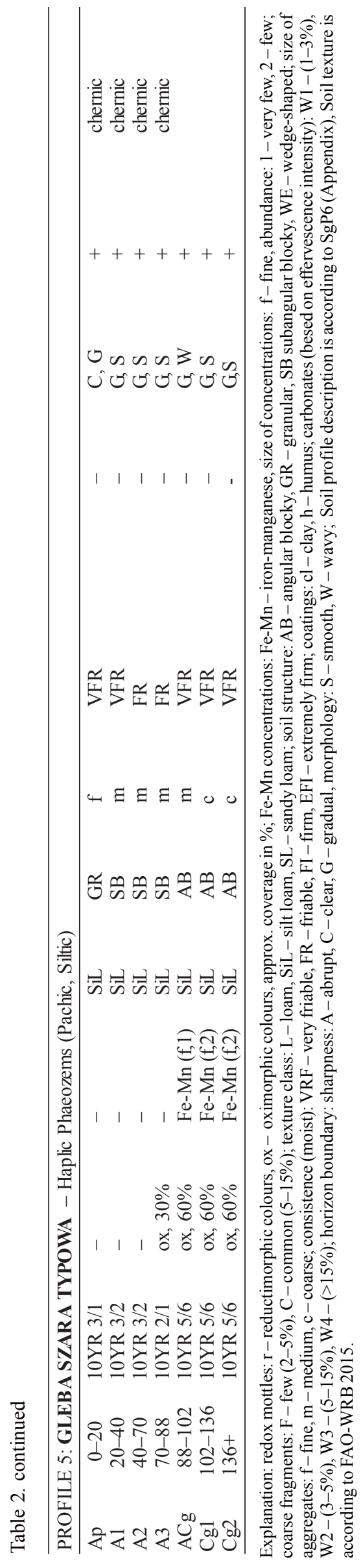

profile 4 represents the soils developed from loess colluvium (silty clay loam texture in topsoil) above the Neogene clays (heavy clay texture class).

A joint feature of the analysed soils is the thick and dark-coloured humus horizon, which total thickness varies from 40 to $88 \mathrm{~cm}$. The humus horizon typically has a gradual transition to the underlying horizon resulting from high activity of soil fauna, especially anecic earthworms, whose corridors are visible to the depth of up to $115 \mathrm{~cm}$. Humus horizons have a dark grey or almost black colour (value 2-3 and chroma 1-2, moist), and a hue that is in most cases 10YR, although in moister soils (as in profile 3 ) a $2.5 \mathrm{Y}-5 \mathrm{Y}$ hue may occur (table 2). In most cases, the soil colour does not change throughout the humus horizon (profiles 2-4). In other soils (profiles 1 and 5) value and chroma vary, but by no more than one unit.

All soils have granular or blocky subangular structure in the topsoil horizons, that changes to a subangular structure in the underlying humus subhorizons, and to angular bloky structure in the parent material. Also, the wedge-shaped (lenticular) structure may be noted in clayey subsoils (profile 4). Structura aggregates in topsoil are in majority medium sized in the case of granular structures, and fine-medium sized in the case of blocky subangular structures. Larger clods or angular blocks tend to form in some arable soils due to ploughing; however, this 1st level blocky angular structure is always accompanied by a 2nd level (internal) granular or blocky subangular structure, i.e. the angular clods tend to disrupt into finer granules or subangular blocks (Table 2).

Humus horizons contain $1.5-2.3 \%$ TOC in the topsoil plough layers and $1.2-2.1 \%$ TOC in underlying sublayers of the humus horizon (table 4 ), excluding profile 2 , where the TOC content is clearly lower $-1.2 \%$ in plough layer and $0.7 \%$ in the bottom part of the A horizon (table 4). Nitrogen content is sufficiently high in topsoil layers $(0.13-0.20 \% \mathrm{TN})$ to keep the $\mathrm{C}: \mathrm{N}$ ratio at the level of 9-13. Humus horizons generally do not contain carbonates or contain only fine lime clods (table 4). Thus, the $\mathrm{pH}$ of topsoil layers vary from alkaline $\left(\mathrm{pHH}_{2} \mathrm{O} 7.8-8.1\right)$, if carbonates are present, through neutral $\left(\mathrm{pHH}_{2} \mathrm{O}\right.$ 6.9-7.7), to slightly acid $\left(\mathrm{pHH}_{2} \mathrm{O}\right.$ 5.8-6.3). A very high content of exchangeable cations, calcium in particular, accompanied by very low or zero total acidity, results in high base saturation values in humus horizons, ranging from 87 to $100 \%$ (Table 4 ).

All soils, excluding the profile 5, contain secondary carbonates at some depth; however, both their content and accumulation depth differ significantly (Table 4). Profile 3 contains carbonates throughout the profile, and its carbonate content is the highest among the profiles under study, reaching ca. $20 \%$ at the depth of $55-75 \mathrm{~cm}$. In profiles 1 and 4 , secondary carbonates occur directly below the lower boundary of humus horizon. Their concentration reaches $5 \%$ (required for protocalcic properties) directly below the humus horizon and their maximum accumulation (ca. 10\%) is at a depth of 110-160 cm and $60-90 \mathrm{~cm}$, in profiles 1 and 4, respectively (table 4). The presence of carbonates results in alkaline reaction within the subsoil layer in all soil profiles $\left(\mathrm{pHH}_{2} \mathrm{O}\right.$ up to 8.6) or neutral reaction $\left(\mathrm{pHH}_{2} \mathrm{O}\right.$ 7.0-7.2), as in the case of profile 5 , if the carbonates are completely leached. As expected, at alkaline reaction and the presence of carbonates, the base saturation is $100 \%$ or nearly $100 \%$ in all subsoil horizons (Table 4). 


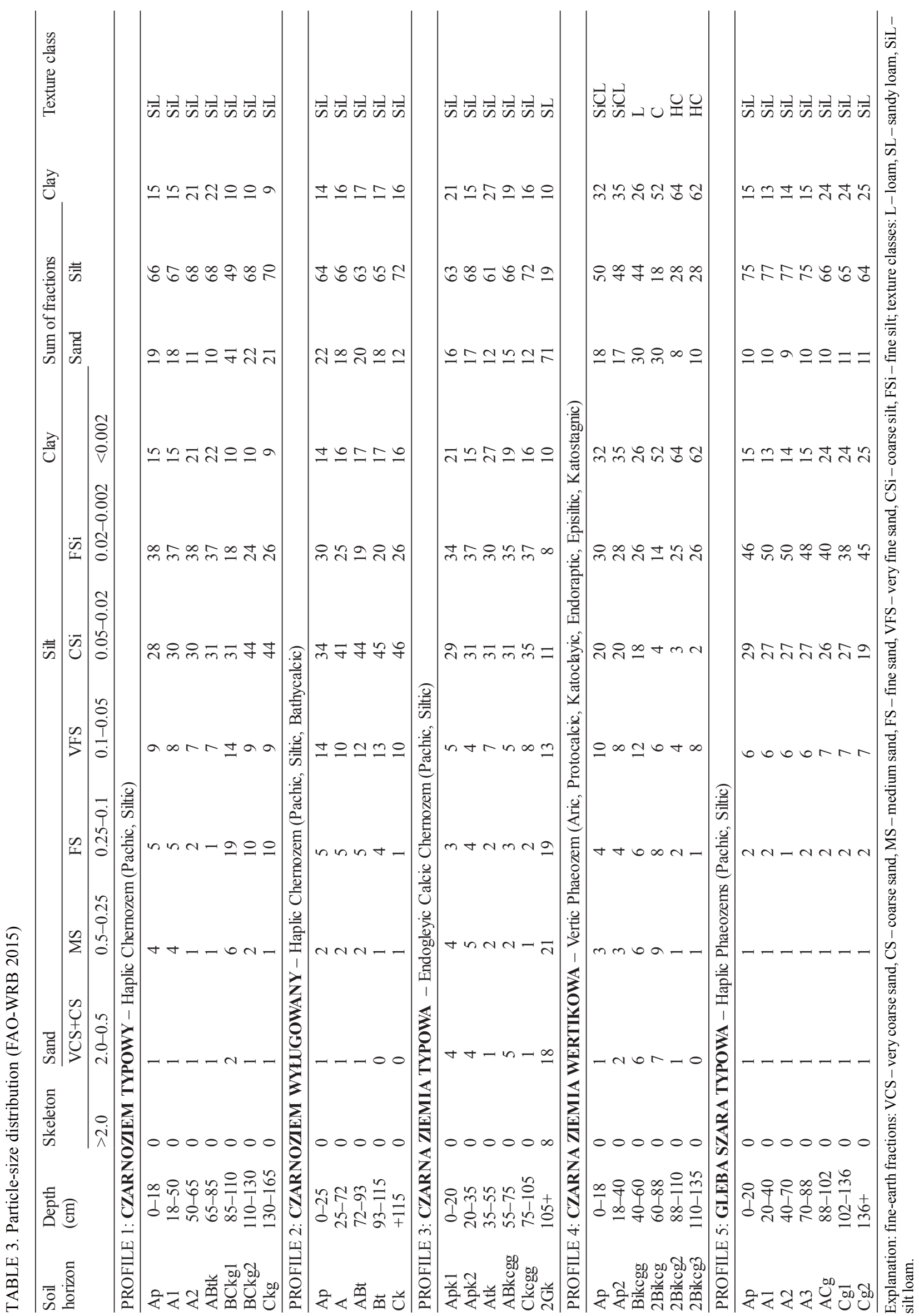




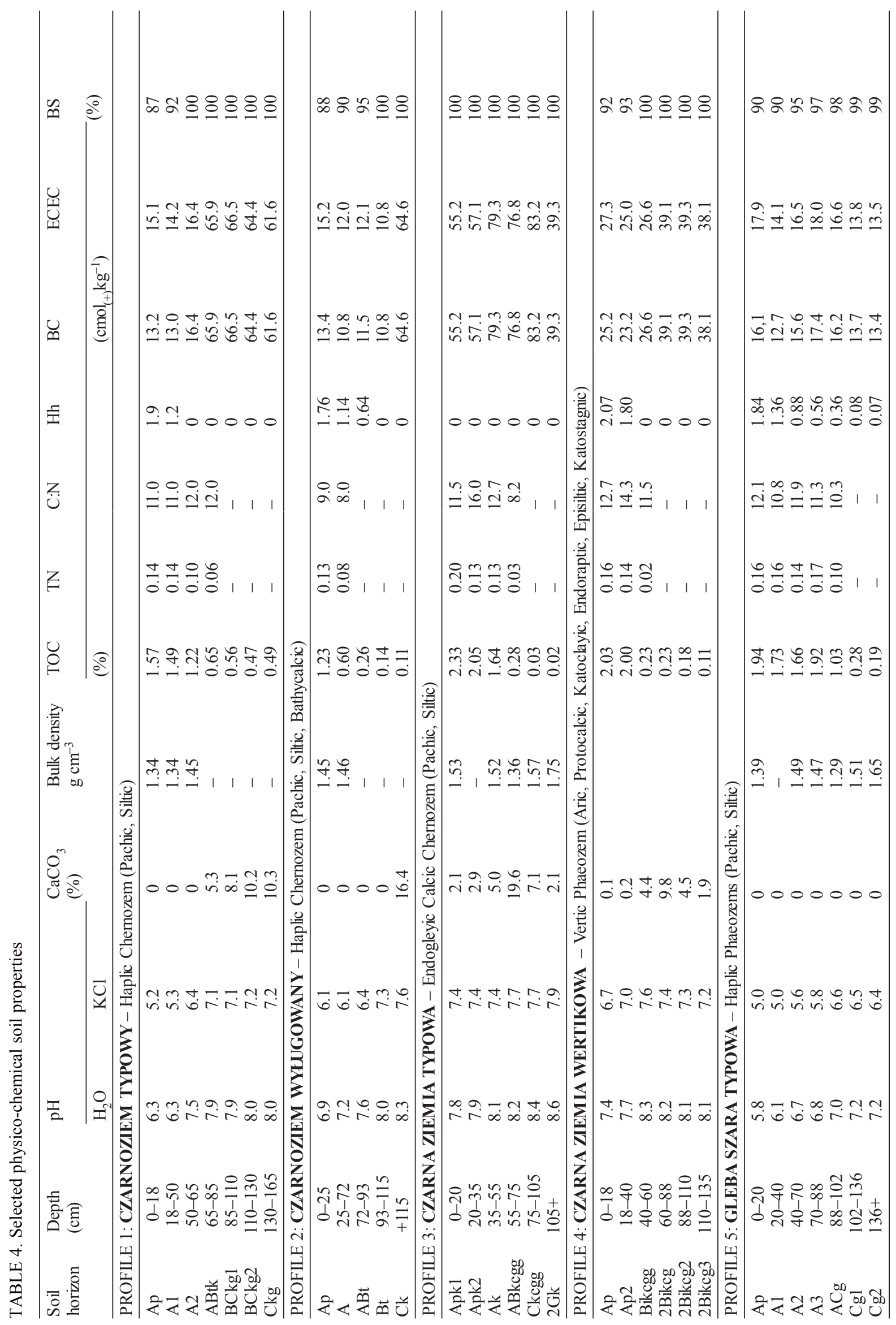


There are redox features in most soils under study. Typically, redox mottling and Fe/Mn accumulations are absent in humus horizons or occur only in their lowest sections (profile 5). A larger abundance of redox mottling, 40-70\%, occurs by the depth of $40-85 \mathrm{~cm}$. Most often, it is a mosaic of reductomorphic and oximorphic colours typical for stagnic properties; however, in the layers featured by high expression of reductomorphic colours, gleyic properties may also occur (profile 4). The mosaic of redox mottling is typically accompanied by the fine soft accumulations of $\mathrm{Fe}+\mathrm{Mn}$, and less frequently by $\mathrm{Fe}$ or $\mathrm{Mn}$ alone. Only in profile 2 were the redox features minimally developed or absent (Table 2).

The transition between humus and subsoil horizons of AC type, considered typical for chernozems, was reported in only one case (profile 5), whereas the transition of $\mathrm{AB}$ type prevailed in other profiles (Table 2), recognised based on the structure and colour development in the transitional zone. Moreover, clay or clay/humus cutans were identified in the channels, pores and walls of structural aggregates in the bottom part of humus horizon and in the transitional layers of some profiles (Table 2), indicating weak clay and humus illuviation. The clayey transitional and subsoil layers in the profile 4 have a specific angular and wedge-shaped structure, shining aggregate surfaces (slickensides), and parallelly grooved surfaces of wedge-shaped (lenticular) aggregates, indicating the shrink-swell phenomena.

\section{DISCUSSION}

\section{Diagnostic features and soil classification}

All soils under comparison have topsoil horizons featured by: (a) black or nearly black colours (Munsell value $2-3$ and chroma $1-2$, moist), (b) pedogenic granular or blocky subangular structure, (c) at least $1.2 \%$ of organic carbon, (d) base saturation $>95 \%$, and (e) thickness of dark humus horizon of at least $40 \mathrm{~cm}$. Thus, all soils have a well-developed mollic horizon (IUSS Working Group WRB 2015). Moreover, in all cases, at least the upper part of the mollic fulfils the criteria of a chernic horizon, i.e. more than $1 \%$ of organic carbon, chroma 2 (moist), and granular or a fine blocky subangular structure (Table 2 and 4 ).

Soils 2 and 3 are featured by high accumulation of secondary carbonates in certain subsurface layers (up to 16.4-19.6\%), resulting in the presence of macroscopically identifiable accumulations such as hard nodulae, channel infillings, carbonate coatings, etc. Based on these features, calcic horizons have been recognized at a depth of $115 \mathrm{~cm}$ and $55 \mathrm{~cm}$, in profiles
2 and 3, respectively, that is $0-43 \mathrm{~cm}$ below the lower boundary of mollic horizon. Carbonates in the other soil profiles are more intensely leached, thus their accumulation in profiles 1 and 4 is not high enough for a calcic horizon, but fulfils the requirements for protocalcic properties. In both profiles, the layer with protocalcic properties begins less than $50 \mathrm{~cm}$ below the lower limit of mollic horizon.

The presence of a chernic horizon and calcic horizon or protocalcic properties that appear less than $50 \mathrm{~cm}$ below the mollic/chernic horizon makes it appropriate to classify these soils as Chernozems (IUSS Working Group WRB 2015). Profile 3 was classified as Calcic Chernozem, and profiles 1 and 2 - as Haplic Chernozems, due to the deeper location of the calcic horizon $(<100 \mathrm{~cm}$ from the soil surface) or the presence of protocalcic properties instead of a calcic horizon.

Most of soils under study have a relatively strong expression of redoximorphic features (excluding the profile 2), but the features are present too deep for them to be considered Gleysols and Stagnosols (IUSS Working Group WRB 2015). However, the criteria for Gleyic principal qualifier are met in profile 3 (below the depth of $55 \mathrm{~cm}$ ) and the criteria for Stagnic supplementary qualifier are fulfilled in profiles 1 and 3 (Table 2). The soil in profile 4 has a welldeveloped vertic horizon (clay texture class, wedgeshaped structure, slickensides on aggregate wells, filled cracks, etc.); however, a coarser texture of topsoil horizons eliminated this soil from Vertisols and shifted it to Vertic Chernozems.

The soil in profile 5 has a thick chernic horizon; however, it does not have secondary carbonates, thus cannot be classified as a Chernozem, and, following the key to Soil Reference Groups of WRB, is considered to be a Phaeozem. Phaeozems have a mollic horizon accompanied by high base saturation ( $>50 \%)$ down to the depth of $100 \mathrm{~cm}$, while the secondary carbonates may be leached much deeper or even completely absent (IUSS Working Group WRB 2015). The presence of a chernic horizon and strongly expressed stagnic properties (starting at the depth of $88 \mathrm{~cm}$ ) justified soil classification as Endostagnic Chernic Phaeozem (Table 2).

All soils under study are under permanent cultivation and feature a surface plough layer that is sharply cut off from underlying horizons; therefore, the supplementary qualifier Aric was added to all soil names. Most soils (excluding profile 3 ) have a mollic/ chernic horizon thicker than $50 \mathrm{~cm}$ that justified the addition of the Pachic supplementary qualifier. Moreover, the silt loam texture class supports the adding of the Siltic qualifier in all soils excluding 
profile 4, where the Episiltic and Katoclayic qualifiers are more appropriate to reflect the different texture of this soil, along with the Endoraptic qualifier to reflect its lithic discontinuity.

The Polish equivalents for soils under study are more variable at the basic level of classification (Kabała et al. 2019a, Kabała 2019b). Only profiles 1 and 2 are classified as 'czarnoziem', whereas profiles 3 and 4 have too strong expression of redoximorphic features and therefore must be classified as 'czarne ziemie' (black earths). Profile 5 cannot be included in 'czarnoziemy' or 'czarne ziemie', because it does not have secondary carbonates and its redoximorphic features are present too deep. Finally, the soil in profile 5 was classified as 'gleba szara' (grey soil), a new soil type distinguished in Polish soil Classification (Kabałaetal.2019a)

More detailed insight allows the following classification on a subtype level: profile 1 - 'czarnoziem typowy' (typical chernozem), because the soil has a mollic horizon, secondary carbonates at the depth of $<100 \mathrm{~cm}$, and redoximorphic features that start deeper than $80 \mathrm{~cm}$ from the soil surface; profile $2-$ 'czarnoziem wyługowany' (leached chernozem), because its secondary carbonates are leached below the depth of $100 \mathrm{~cm}$ (and redoximorphic features start deeper than $80 \mathrm{~cm}$ from the soil surface); profile 3 'czarna ziemia typowa' (typical black earth), as the soil has a mollic horizon, a strong expression of stagnic/gleyic properties in the middle part of soil profile, and carbonates within $100 \mathrm{~cm}$ from the soil surface; profile 4 - 'czarna ziemia wertikowa' (vertic black earth), due to the presence of mollic and vertic horizons and strong expression of stagnic/gleyic properties in the middle part of soil profile; and profile 5 -'gleba szara typowa' (typical grey soil), due to the presence of a mollic horizon, the absence of secondary carbonates in the soil profile, and the absence of redoximorphic features in the middle part of soil profile (although they may be present deeper than $80 \mathrm{~cm}$ from the soil surface).

\section{Origin of soils and reasons for their variability}

It is very difficult unambiguously establish the genesis, age, and conditions of the formation of chernozemic soils in the Silesian Lowland and the Sudety Foreland. In these soils, there is a constant process of renewing the organic matter as a result of intense zooturbation, which leads to mixing of material from deeper and shallower soil horizons (Vyslouzilova et al. 2014a, Łabaz et al. 2018) what makes it impossible to determine the age of soil based on the age of organic matter. Also, it is difficult to determine the type of vegetation conducive to the formation of chernozemic soils due to the fact that the plant pollen is quickly decomposed in these soils. External palynological arguments, that come from the completely different environments (of lakes or peat deposits), even if they are located in the direct vicinity of chernozemic soils under investigations (Barczi et al. 2006, Malkiewicz et al. 2010, 2016). Similarly, malacological studies mentioned by some authors (e.g. Eckmeier et al. 2007) are unreliable due to the rapid disintegration of carbonate shells of molluscs in decalcified humus horizons. Therefore, many key questions related to the genesis and age of chernozemic soils remain unanswered, and existing reconstructions of the soil cover evolution are largely based on indirect evidence from fossil and other soils that were preserved in archaeological sites (Alexandrovskiy et al. 2014, Eckmeier et al. 2007, Ehwald et al. 1999, Kabałla et al. 2019b).

In southwest Poland, there are debates surrounding two basic questions related to the origin of chernozemic soils, namely, (a) is it possible that the deep humus horizons in loess-derived chernozems and black earths have a similar genesis, and (b) are the preserved chernozemic soils relics of the Late-Pleistocene or eventually Early-Holocene periods, or rather were they formed much later - in the Neolithic period?

The first above-mentioned problem arises from a long Polish tradition of separate treatment of black earths, to which Miklaszewski (1930) attributed postswampy genesis, i.e. he admitted that they were formed from organic or mineral-organic lake sediments that appeared on the surface due to the drying of the lake basin. Miklaszewski (1930) characterised these soils based on the morphological features of humus horizons that were created by ploughing. There are many such soils in Poland, and they have very different morphological, textural, and physico-chemical characteristics (Strzemski 1954). Their common feature is their location in the depressions, which in the past were water reservoirs or swampy or heavily waterlogged areas. They are young soils, created as a result of regulatory and drainage projects (Labaz and Kabała 2014). However, Kowaliński (1952) reported that the black earths developed from loess at higher elevations and even on hill-tops should not be considered to be soils created by drying lakes or swamps, but rather as meadow soils, developed in course of the intensive accumulation of turf organic matter under seasonally excessive moisture conditions. In numerous patches of black earths in south-western Poland, many transitional forms have been noted, i.e. soils that have medium or low intensity of redox features in their profile, where even wet-meadow origin may be problematic to assign (Drozd et al. 2007). 
The most spectacular are soil catenae in the southern part of the Silesian Lowland and in the Sudeten Foreland, where on one gentle hillslope, on a relatively short distance, both the typical 'moist' black earths (with strong gleyic features) and the most typical 'dry' chernozems (without any redoximorphic features) may be adjacent (Labaz et al. 2018). These soils are developed from the same parent material (loess), have almost identical texture and very similar morphology, including the thickness of their humus horizons, depths of carbonate leaching, and similar physico-chemical properties, including the humus content. It does not seem possible that these adjacent and such a similar soils, which morphology and properties change gradually within slope catena, have developed totally independently as the chernozem a steppe soil and the black earth - a swamp soil. Also, the large thickness of the humus horizons, often exceeding $50 \mathrm{~cm}$, suggests that the same factors have led to formation of all these horizons. It does not seem possible that such a deep humus horizon could arise solely due to the accumulation of turf organic matter; this contradicts the fact that many moist or even waterlogged meadow soils have a humus horizon no deeper than 10-20 cm (Kabała et al. 2015a). It is believed, that for the formation of such deep humus horizons, intensive and long-term zooturbation is necessary, which is only possible in either dry soils or soils with a regulated water regime (Jenny 1994). Similar mosaics of 'dry' and 'moist' chernozems have been identified in the Kursk and Voronezh steppes in Russia, where all chernozemic soils were attributed to similar genesis (connected with continental climate and steppe vegetation), though some became moist in the later period following the onset of increasingly humid climatic conditions (Khitrov and Loiko 2010). It seems that in south-western Poland, all loessderived chernozemic soils (excluding the alluvial and deluvial/colluvial chernozemic soils) could have a similar origin, that is they developed under steppe, forest-steppe, or meadow-forest vegetation, under moderate humidity rather than under high moisture conditions.

A similar hypothesis is also presently adopted for Saxonian chernozemic soils (Ehwald et al. 1999). In this approach, the redox features, including strong stagnic or gleyic properties, are secondary features, developed at later times (during subsequent periods of humid climate), perhaps in the Subatlantic period. This is indirectly demonstrated by the intensive development of settlements on the Wrocław Plain during the Neolithic period (Kulczycka-Leciejewiczowa 1993). These areas could not have been subject to such intensive agricultural colonization if they were wetlands at that time. In addition, numerous grains of feather grass (Stipa sp.) identified in the Neolithic archaeological sites on the Wrocław Plain testify to the steppe nature of vegetation in that period (Chmielewski et al. 2014), and thus the lack of excessive moisture of soils in these areas.

The second of these problems raises much controversy among European soil experts (Lorz and Saile 2011), including those in Poland, where the same features of contemporary and fossil soils are interpreted differently (Borowiec 1968, Maruszczak 1998, Turski 1985). Dating of the organic matter accumulated in the lower part of the humus horizon of the buried chernozem under a Neolithic kurgan near Henryków showed a late Pleistocene age, of 11,046-10,721 cal BCE or 12,671-12,996 cal BP (Kabała et al. 2019b). Since the end of the Pleistocene and beginning of the Holocene, the forest-tundra vegetation, rich in species of grasses and herbaceous perennials, has contributed to the formation of chernozems (Malkiewicz et al. 2010). Even if we assume that the dates given above do not represent the real age but so-called mean residence time (MRT) of organic matter in the soil (Poręba et al. 2011), it should be recognized that in the period of construction of kurgans, this area was covered with chernozems containing organic matter that had accumulated since the late Pleistocene. On the other hand, the datings for the "surface" chernozems in Trzebnik-Radzików area (Lagiewniki region) show a Holocene age/MRT (3,383-3,557 cal BP) for the organic matter in the lower part of the humic horizon (Łabaz et al. 2018). These dates exceeding 3,000 cal $\mathrm{BP}$ are considered to indicate the accumulation of organic matter since at least the Neolithic period (Eckmeier et al. 2007; Vyslouzilova et al., 2014b). Regardless of the interpretation of ${ }^{14} \mathrm{C}$ dating of the organic matter in "surface" chernozems, it should be understood that since the Neolithic period, large amounts of humified organic matter have been accumulated in these soils and created very thick humus horizons, sometimes even twice as thick as those in the fossil chernozems under kurgans (Kabała et al. 2019b, Labaz et al. 2018).

Although most authors support one period of chernozem formation in Poland, either the Late Pleistocene (Borowiec 1968) or Subatlantic/Neolithic (Maruszczak 1998), it cannot be ruled out that on the loess areas of southern Poland and possibly in Central Europe, there were two phases of chernozem formation: both in the Late Pleistocene and Subatlantic/Neolithic periods (Kabała et al. 2019b). It also cannot be ruled out that the Neolithic phase happened in the same soils, which developed as chernozems at the end of the Pleistocene and persisted to the Neolithic period 
without transforming into other soil types. No clayilluviation, which could indicate the transformation of early Holocene chernozems into Luvisols during the Atlantic climate optimum, was identified in the profiles buried under Neolithic kurgans near Henryków (Kabała et al 2019b). This indicates that the older (Late Pleistocene) chernozems could survive until the Neolithic period and underwent a second 'chernozemic' phase, resulting in the humus horizons being 'rejuvenated' and thickened.

Comparison of morphological and physico-chemical properties of buried and 'modern/surface' chernozems indicates that the humus horizons created/transformed during the Neolithic chernozemic phase (and later) are deeper and more abundant in organic matter (Labaz et al. 2018; Kabała et al. 2019b). This was aided by the elimination of forests and the establishment of permanent agricultural land-use, which drastically changed the kind of biomass inflow, including the elimination of a forest litter. On the other hand, in areas that have undergone further afforestation (such as the kurgans and their immediate vicinity in the Muszkowicki Forest), intensive leaching of carbonates and basic cations started, followed by the decomposition of organic matter in topsoil and dislocation of clay fractions, eventually leading to the complete disappearance of humus horizons and formation of eluvial and illuvial horizons, typical for the forest Luvisols. Many transitional stages of this kind soil transformation have been described, including soils that still are featured by chernozem-type morphology, but also are depleted of carbonates and basic cations, and have clearly morphologically manifested clay and humus translocation (Kowaliński et al. 1987), whereby corresponding to so-called grey forest soils, widespread in the northern forest-steppe zone of Russia and Ukraine (Miedema et al. 1999).

Contemporary differentiation of chernozemic soils in south-western Poland results not only from the primary origin of these soils, leading to the formation of thick humus horizons, but also from (a) climatic conditions translating into soil moisture, (b) soil location in the landscape that affects the water regime in the profile and the activity of geomorphological processes, (c) parent materials, and (d) human activity. If it is assumed, that the large spreading of feathergrass (Stipa sp.) in the loess areas of the Silesian Lowland during the Neolithic period (Chmielewski et al. 2014) is an indicator of the predominance of steppe-type vegetation and a rather dry climate during that period, it should be accepted that the strong stagnic or gleyic properties, so frequently found in the chernozemic soils of the Silesian Lowland, were formed later, e.g. in the Subatlantic humid climatic phases (Starkel 1977).
A regional groundwater rise during these phases led to the appearance of gleyic properties, as well as a stronger rainwater accumulation in soils featured by finer texture and the formation of stagnic properties in these soils.

In this context, loess-derived black earths should be considered chernozems, which acquired the redoximorphic features as secondary properties in the younger Holocene. Undoubtedly, the contemporary water stagnation in soil profiles, which is manifested by stagnic/gleyic properties, affects the physicochemical properties of these soils by, for example, inhibiting carbonate leaching and mineralization (decomposition) of humus, which contributes to a higher accumulation of organic matter in A horizons of moister chernozemic soils, i.e. black earths (Kowalinski 1952, Borowiec 1968, Turski 1985).

Higher climatic humidity in the younger Holocene contributed to stronger leaching of carbonates in soils occurring under good drainage conditions. Nowadays, loess-derived chernozemic soils quite commonly are completely devoid of carbonates to a depth of $150 \mathrm{~cm}$ and deeper (Drozd et al. 2007, Kowaliński et al. 1987).

The soil texture and especially the texture discontinuities (lithogenic discontinuity) in the soil profiles undoubtedly affect the direction of chernozemic soil transformation. In the soils that have sands, gravels, and other highly permeable sediments in the subsoil, much stronger leaching of carbonates may occur, and soils can more often be completely deprived of carbonates (Dudek et al. 2019). In turn, the heavy loamy texture in subsoil may promote the water stagnation in an overlying loess and formation of the redox mosaic in the middle part of the profile (Labaz and Kabała 2014). In the case of very fine (clayey) sediments underlying the loess topsoil, a seasonally alternating strong water saturation and strong soil drying could activate the shrink-swell phenomena, which lead to the formation of a vertic horizon below the mollic one, accompanied by strong expression of stagnic properties in the middle and lower parts of the profile (Kabala et al. 2015b). Such soils are classified in Poland as vertic black earths (Kabała et al. 2019a).

\section{CONCLUSIONS}

In the loess-belt that extends in the south-western Poland, many isolated spots of chernozemic soils were identified. The common feature of these soils is a thick mollic horizon, rich in humus, dark-coloured, structural, and saturated with base cations. Despite these soils differ presently in many morphological features, including the presence of redoximorphic features, it is believed, that most of these soils has a similar initial - 
chernozemic - history of their thick humus horizon, which started under the steppe or forest-steppe vegetation and under moderately humid climate. However, the typical chernozems, i.e. soils which have a mollic horizon and secondary carbonates, but do not have strong redoximorphic features, are rather rare in loess-belt of SW Poland. Instead, the black earths predominate, that are soils with mollic horizons and strong gleyic or stagnic features in the middle and bottom parts of their profiles (carbonates may or may not be present in the profile). These soils were created as chernozems and acquired the gleyic or stagnic properties as a result of the climate moistening in the younger Holocene. They occur in various forms (subtypes), formed under different topographical and water conditions and under the influence of different underlying bedrocks. Vertic black earths developed on the clayey subsoil are the most notable, along with the leached black earths, developed on the permeable subsoils and lacking carbonates. Chernozemic soils existing under good drainage conditions are free of gleyic/stagnic properties; however, they may be completely devoid of carbonates and deeply depleted of base cations. These soils are classified as grey soils, in which secondary pedogenic processes (resulting in a formation of subsurface cambic or argic horizons) can develop on a larger scale. The mosaic-like spread of chernozemic soils in the loess belt of SW Poland may be a result of permanent agricultural use (since Neolithic period to modern times) of some chernozems, which preserved them from degradation, while the other soils, permanently afforested until modern times, have transformed into Luvisols.

\section{ACKNOWLEDGMENTS}

Researches financed from the project (B030/0019/18).

\section{REFERENCES}

Alexandrovskiy A.L., Sedov S.N., Shishkov V.A., 2014. The development of deep soil processes in ancient kurgans of the North Caucasus. Catena 112: 65-71.

Badura J., Jary Z., Smalley I., 2013. Sources of loess material for deposits in Poland and part of Central Europe: The lost Big River. Quaternary International 296: 15-22.

Barczi A., Tóth T.M., Csanádi A., Sümegi P., Czinkota I., 2006. Reconstruction of the paleo-environment and soil evolution of the Csípo-halom kurgan, Hungary. Quaternary International 156: 49-59.

Borowiec J., 1968. The problem of typology and development trends of chernozems occurring in Poland. Roczniki Gleboznawcze - Soil Science Annual 19(1): 253-260.

Chmielewski T.J., Furmanek M., Patay R., Sady A., 2014. Needle grass (Stipa sp.) in the Neolitic and Eneolithic periods in Central Europe. Contribution to the discussion on the phenomenon. Arheovest, JatePress Kiado, Szeged, Hungary: 109-133.

Dokuchaev V.V., 1883. Russkij Chernozem. Sankt Petersburg: $376 \mathrm{pp}$.

Drewnik M., Żyła M., 2019. Properties and classification of heavily eroded post-chernozems soils in Proszowice Plateau (southern Poland). Soil Science Annual 70/3: 225-233.

Drozd J., Piątek J., Łabaz B., 2007. Properties of the Chernozem soils in Kłodzko basin. Zeszyty Problemowe Postępów Nauk Rolniczych 520: 447-454.

Dudek M., Waroszewski J., Kabała C., Łabaz B., 2019. Vertisols properties and classification in relation to parent material differentiation near Strzelin (SW Poland). Soil Science Annual 70(2): 158-169

Eckmeier E., Gerlach R., Gehrt E., Schmidt M.W.I., 2007. Pedogenesis of Chernozems in central Europe - A review. Geoderma 139: 288-299.

Ehwald E., Jäger K.D., Lange E., 1999. Das Problem Wald Offenland im zirkumherzynen Trockengebiet von der neolithischen Besiedlung sowie die Entstehung der zirkumherzynen Schwarzerden. Hamburger Werkstattreihe zur Archäologie 4: 12-34.

Firbas F., 1949. Über das Verhalten von Artemisia in einigen Pollendiagrammen. Biol. Zbl. 67: 17-21.

Hohenstein V., 1919. Die ostdeutsche Schwarzerde (Tschernosem). Internat. Mitt. Bodenkunde 9: 1-31.

IUSS Working Group WRB, 2015. World Reference Base for Soil Resources 2014, Update 2015. International soil classification system for naming soil and creating legends for soil maps. Food and Agriculture Organization of the United Nations, Rome.

Jary Z., 2010. Loess-soil sequences as a source of climatic proxies: an example from SW Poland. Geologija 52(1-4): 69-72.

Jenny H., 1994. Factors of soil formation: a system of quantitative pedology. Courier Corporation: $191 \mathrm{pp}$.

Kabała C., Bekier J., Bińczycki T., Bogacz A., Bojko O., Cuske M., Ćwieląg-Piasecka I., Dębicka M., Gałka B., Gersztyn L., Glina B., Jamroz E., Jezierski P., Karczewska A., Kaszubkiewicz J., Kawałko D., Kierczak J., Kocowicz A., Krupski M., Kusza G., Łabaz B., Marzec M., MedyńskaJuraszek A., Musztyfaga E., Perlak Z., Pędziwiatr A., Pora E., Przybył A., Strączyńska S., Szopka K., Tyszka R., Waroszewski J., Weber J., Woźniczka P., 2015a. Soils of Lower Silesia: origins, diversity and protection. PTG. PTSH. Wrocław: $256 \mathrm{pp}$.

Kabala C., Plonka T., Przekora A., 2015b. Vertic properties and gilgai-related subsurface features in soils of south-western Poland. Catena 128: 95-107.

Kabała C., 2019. Chernozem (czarnoziem) - soil of the year 2019 in Poland. Origin classification and use of chernozems in Poland. Soil Science Annual 70/3: 184-192.

Kabała C., Charzyński P., Chodorowski J., Drewnik M., Glina B., Greinert A., Hulisz P., Jankowski M., Jonczak J., Łabaz B., Łachacz A., Marzec M., Mendyk Ł., Musiał P., Musielok Ł., Smreczak B., Sowiński P., Świtoniak M., Uzarowicz Ł., Waroszewski J., 2019a. Polish Soil Classification, 6th edition - principles, classification scheme and correlations. Soil Science Annual 70(2): 71-97.

Kabala C., Musztyfaga E., 2016. Clay-illuvial soils in the Polish and international soil classifications. Soil Science 
Annual 66(4): 204-213.

Kabała C., Przybyl A., Krupski M., Labaz B., Waroszewski J., 2019b. Origin, age and transformation of Chernozems in northern Central Europe - New data from Neolithic earthen barrows in SW Poland. Catena 180: 83-102.

Khitrov N.B., Loiko S.V., 2010. Soil cover patterns on flat interfluves in the Kamennaya Steppe. Eurasian Soil Science 43: 1309-1321.

Komisja Klasyfikacji, Nomenklatury i Klasyfikacji Gleb PTG, 1956. Przyrodniczo-genetyczna klasyfikacja gleb Polski. Wyd. 1. Roczniki Nauk Rolniczych 74: 10-96.

Komisja Klasyfikacji, Nomenklatury i Klasyfikacji Gleb PTG, 1959. Przyrodniczo-genetyczna klasyfikacja gleb Polski. Wyd. 2. Roczniki Gleboznawcze - Soil Science Annual 7(2): $103 \mathrm{pp}$.

Kondracki J., 2002. Geografia regionalna Polski. Wydawnictwo Naukowe PWN, Warszawa: 457 pp.

Kowaliński S., 1952. Czarne ziemie Wrocławskie. Roczniki Gleboznawcze - Soil Science Annual 2: 59-91.

Kowaliński S., Licznar M., Drozd J., Licznar S.E., 1987. Mikromorfologiczna interpretacja procesów fizyko chemicznych w glebach czarnoziemnych różnych rejonów Polski. Roczniki Gleboznawcze - Soil Science Annual 38(2): 77100.

Kulczycka-Leciejewiczowa A., 1993. Neolithic settlement in south-western Poland. An outline of spatial organization. Polish Academy of Sciences, Wroclaw, Poland: 223 pp.

Łabaz B., Kabała C., 2014. Origin, properties and classification of black earths in Poland. Soil Science Annual 65(2): 80-90.

Labaz B., Kabala C., 2016. Human-induced development of mollic and umbric horizons in drained and farmed swampy alluvial soils. Catena 139: 117-126.

Łabaz B., Musztyfaga E., Waroszewski J., Bogacz A., Jezierski P., Kabala C., 2018. Landscape-related transformation and differentiation of Chernozems - Catenary approach in the Silesian Lowland, SW Poland. Catena 161: 63-76.

Labaz B., Kabala C., Waroszewski J., 2019. Ambient geochemical baselines for trace elements in Chernozems-approximation of geochemical soil transformation in an agricultural area. Environmental Monitoring and Assessment 191(1): 19.

Lorz C., Saile T., 2011. Antropogenic pedogenesis of Chernozems in Germany? - A critical review. Quaternary International 243: 273-279.

Malkiewicz, M., Tomaszewska, K., Sadowski, K., 2010. An attempt to reconstruct the natural environment in the Late Vistulian-Holocene in Domasław near Wrocław. [In:] Żurek S. (Ed.), Interdisciplinary investigation - past, today and future of natural science. Proceedings of the conference. Jan Kochanowski University, Kielce, Poland: 81-82.

Malkiewicz M., Waroszewski J., Bojko O., Egli M., Kabala C., 2016. Holocene vegetation history and soil development reflected in the lake sediments of the Karkonosze Mountains (Poland). The Holocene 26(6): 890-905.

Maruszczak H., 1998. Wpływ gospodarki neolitycznej na rozwój tzw. czarnoziemów hrubieszowsko-tomaszowskich. Przegląd geograficzny 70(3-4): 333-342.
Miedema R., Koulechova I.N., Gerasimova M.I., 1999. Soil formation in Greyzems in Moscow district: micromorphology, chemistry, clay mineralogy and particle size distribution. Catena 34(3): 315-347.

Miklaszewski S., 1930. Gleby Polski. Warszawa: 638 pp.

Orth A., 1872. Geognostische Durchforschung des Schlesischen Schwemmlandes zwischen dem Zobtener und Trebnitzer Gebirge nebst analytischen und petrographischen Bestimmungen sowie einer Uebersicht von Mineral-Gestein und Bodenanalysen. Wiegandt \& Hempel, Berlin: 361 pp.

Poręba G., Śnieszko Z., Moska P., 2011. Some aspects of age assessment of Holocene loess colluvium: OSL and 137Cs dating of sediment from Biała agricultural area, South Poland. Quaternary International 240(1-2): 44.

Ramann E., 1911. Bodenkunde. Verlag J. Springer, Berlin: 619 pp. Starkel L., 1977. Paleogeografia holocenu. PWN, Warszawa: 362 pp. Stremme H., 1930. Die Boeden Deutschlands. [In:] Blanck E. (Ed.), Handbuch der Bodenlehre. Teil 5. Verlag J. Springer, Berlin: 271-426.

Stremme H., 1937. International Soil Map of Europe, 1:2 500000. Gea Verlag, Berlin.

Strzemski M., 1954. „Czarne ziemie” jako wskaźnik odwodnienia kraju. Gospodarka Wodna 2: 1-46.

Systematyka gleb Polski, 2011. Roczniki Gleboznawcze - Soil Science Annual 62(3): 1-193.

Systematyka gleb Polski, 2019. Polskie Towarzystwo Gleboznawcze, Komisja Genezy Klasyfikacji i Kartografii Gleb. Wydawnictwo Uniwersytetu Przyrodniczego we Wrocławiu, Polskie Towarzystwo Gleboznawcze, Wrocław-Warszawa: 395 pp.

Turski R., 1985. Geneza i właściwości czarnoziemów Wyżyny Zachodniowołyńskiej i Lubelskiej. Roczniki Nauk Rolniczych $\mathrm{D}(202)$ : $156 \mathrm{pp}$.

Vyslouzilova B., Dankowa L., Ertlen D., Novak J., Schwartz D., Sefrna L., Delhon C., Berger J.-F., 2014a. Vegetation history of chernozems in the Czech Republic. Vegetation history and archaeobotany 23: 97-108.

Vyslouzilova B., Ertlen D., Sefrna L., Novak T., Viragh K., Rue M., Campaner A., Dreslerova D., Schwartz D., 2014b. Investigation of vegetation history of buried chernozem soil using near-infrared spectroscopy (NIRS). Quaternary International 365: 203-211.

Waroszewski J., Sprafke T., Kabala C., Kobierski M., Kierczak J., Musztyfaga E., Łabaz B., 2019. Tracking textural, mineralogical and geochemical signatures in soils developed from basalt-derived materials covered with loess sediments (SW Poland). Geoderma 337: 983-997.

Waroszewski J., Sprafke T., Kabala C., Musztyfaga E., Łabaz B., Woźniczka P., 2018. Aeolian silt contribution to soils on mountain slopes (Mt. Ślęża, southwest Poland). Quaternary Research 89 (3): 702-717.

Received: August 13, 2019

Accepted: October 1, 2019

Associated editor: A. Lachacz 


\section{Zróżnicowanie morfologiczne gleb czarnoziemnych w Polsce południowo-zachodniej}

Streszczenie: W pasie lessowym Polski południowo-zachodniej, wyspowo występują gleby czarnoziemne, których wspólną cechąjest obecność głębokiego, zasobnego w próchnicę, ciemno zabarwionego, strukturalnego oraz wysyconego zasadami poziomu próchnicznego - mollik. Istnieją przesłanki, że w większości tych gleb, głęboki poziom próchniczny może mieć podobną początkową genezę, utożsamianą z procesem czarnoziemnym, zachodzącym w warunkach stepu lub lasostepu o umiarkowanej wilgotności. Gleby te występują jednak na różnych podłożach skalnych i w różnych warunkach wilgotnościowych, co doprowadziło do rozwoju cech towarzyszących, które zadecydowały o różnej ich pozycji klasyfikacyjnej. Celem pracy jest przedstawienie podtypów gleb czarnoziemnych południowo-zachodniej Polski w odniesieniu do warunków lokalnych, które wpłynęły na ich transformację $\mathrm{i}$ obecne zróżnicowanie przestrzenne. Typowe czarnoziemy (WRB: Calcic Chernozems), gleby mające poziom mollik i wtórne węglany oraz zaznaczające się w niektórych profilach cechy opadowo-glebowe, w Polsce południowo-zachodniej występują rzadko. Przeważają natomiast czarne ziemie, z poziomem mollik oraz wyraźnymi cechami opadowo/gruntowo-glejowymi w środkowej (i dolnej) części profilu (WRB: Gleyic/Stagnic Chernozems/Phaeozems). Gleby te powstały jako czarnoziemy, a właściwości glejowe nabrały w efekcie wzrostu wilgotności klimatu w młodszym holocenie. Występują one w różnych podtypach, ukształtowanych w zróżnicowanych warunkach topograficznych, wodnych oraz przy udziale odmiennych podścielających materiałów macierzystych. Najbardziej wyróżniają się czarne ziemie z poziomem wertik (WRB: Vertic Stagnic Phaeozems) wytworzone z ilastych skał macierzystych, natomiast gleby czarnoziemne położone w warunkach dobrego drenażu i jednocześnie całkowicie pozbawione węglanów oraz zubożone w kationy zasadowe nazywane są glebami szarymi (WRB: Cambic/Luvic Phaeozems).

Stowa kluczowe: czarnoziemy, czarne ziemie, gleby szare, poziom mollik, transformacja gleb 